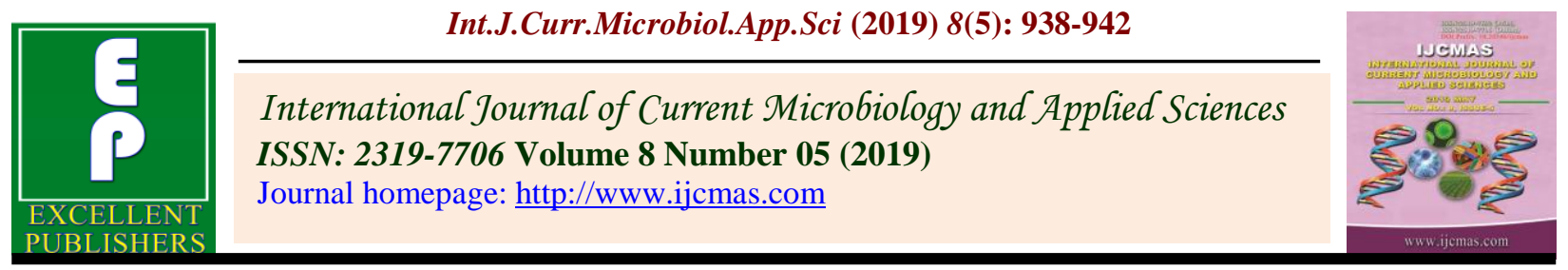

\title{
Study the Effect of Glucanoacetobacter diazotrophicus and PSB Formulations on Quality Parameter on suru Sugarcane
}

\author{
P.P. Khandagale ${ }^{1 *}$, M.M. Keskar ${ }^{2}$, S.K. Ghodke ${ }^{2}$ and B.S. Raskar ${ }^{2}$ \\ ${ }^{1}$ Agricultural Research Station, Niphad, Dist. Nasik ( M.S.), India \\ ${ }^{2}$ Central Sugarcane Research Station, Padegaon, Tal. Phaltan, Dist . Satara ( M.S.), India. \\ *Corresponding author
}

\section{A B S T R A C T}

\begin{tabular}{|l|}
\hline K e y w o r d s \\
Sugarcane, \\
$\begin{array}{l}\text { Saccharum } \\
\text { officinarum L., } \\
\text { PSB, } \\
\text { Glucanoacetobacter } \\
\text { diazotrophicus }\end{array}$ \\
\hline Article Info \\
\hline $\begin{array}{l}\text { Accepted: } \\
10 \text { April } 2019 \\
\text { Available Online: } \\
\text { 10 May } 2019\end{array}$ \\
\hline
\end{tabular}

\section{Introduction}

Sugarcane (Saccharum officinarum L.) is one of the most important food and cash crop of the tropics and subtropics which was cultivated in about 121 countries encompassing approximately half of the world. Sugarcane (Saccharum spp. hybrid) is a tall, perennial grass (family Poaceae, subfamily Panicoide), and is cultivated in tropical and warm-temperate regions between $35^{\circ} \mathrm{N}$ and $35^{\circ} \mathrm{S}$ and from sea level to altitudes of $1,000 \mathrm{~m}$ in a wide variety of soil types (Reis et al., 2007). Most of the commercial sugarcane varieties are hybrids with
Saccharum officinarum. The optimal temperature for sugarcane cultivation is between 20 and $35^{\circ} \mathrm{C}$ and the minimum rainfall requirement is $1,200 \mathrm{~mm}$ per year (Ando, 2010). The stalks (stems) of sugarcane are harvested at 9 to 18 months after planting the mother stem cutting (setts). It over 5.05 million hectare area in the country with a production of 348.19 million tonnes, out of which more than $66 \%$ is concentrated in the sub-tropical states. The production and productivity of sugarcane is severely affected by the various diseases. They are playing an important role in Indian economy and a key role to the socio-economic prosperity in the 
state of Maharashtra. Sugarcane was cultivated on 8.35 lakh hac. area in Maharashtra (2015-16) with the production of 83.79 lakh tone and productivity is $88 \mathrm{t} / \mathrm{ha}$ (Anonymous 2015). The Govt. of India take a decision of blending the ethanol in petrol at $10 \%$ so in future may enhances its importance. Consortiums of endophytic bacteria include various bacteria like, Acetobacter, Agrobacterium, Burkhloderia, Azospirrilum, Herbaspirillum, Azoarcus etc. Acetobacter diazotrophicus now a day's known as Glucanoacetobacter diazotrophicus is an acid loving bacterium requiring $\mathrm{pH}$ of 4.0 to 4.5 for growth and $\mathrm{N}$ fixation. It showed positive growth at 250, 300 and 400C temperature. Among the biofertilizers, the endophytic bacteria Gluconacetobacter and Herbaspirillum are gaining more importance, since they fix atmospheric nitrogen endosymbiotically.

\section{Materials and Methods}

The investigation was carried out at SRS trial at Central sugarcane Research Station, Padegaon, Tal. Phaltan Dist. Satara (Maharashtra) in 2015-16. Soil was medium black it belongs to Inceptisols. The climate of this area is semi-arid. The seedling material of sugarcane Co.M -0265 (Phule - 0265). The experiment was laid out in RBD design on 10.2.2015 with three replications and seven treatments including one control and one recommended dose of fertilizers. Have Plot size, gross $6.0 \times 6.0 \mathrm{~m}$ (5 rows $1.2 \mathrm{~m}$ apart) and net $3.6 \times 5.0 \mathrm{~m}$ ( 3 rows). Plot was harvested at 4.3.2016. Basal dose of nitrogen, phosphorus, and potassium i.e. recommended dose (250:115:115 kg of N, P2O5 and K2O ha-1) along with organic manures i.e. full dose of FYM, Acetobacter diazotrophicus and PSB as per the different treatment details per plot and replication wise were given before transplanting of seedlings. Remaining doses of fertilizers were applied at 6-8, 12-14, and
18-20 weeks after transplanting i.e. top dressing.

\section{Treatment details}

$\mathrm{T}_{1}=$ Absolute control

$\mathrm{T}_{2}=$ Only RDF $\left(100 \% \mathrm{~N}, \mathrm{P}_{2} \mathrm{O}_{5}\right.$ and $\left.\mathrm{K}_{2} \mathrm{O}\right)$.

No Glucanoacetobacter and PSB as set/seedling treatment.

$\mathrm{T}_{3}=$ Set treatment - lignite based culture of G. diazotrophicus $10 \mathrm{~kg}+$ PSB $1.25 \mathrm{~kg}$ in 100 lit water/ha for $30 \mathrm{~min}$ (Recommended check).

$\mathrm{T}_{4}=$ Set treatment - liquid culture of $G$. diazotrophicus@1 lit.+PSB @ 1 lit.in 100 lit water/ha for30 min.

$\mathrm{T}_{5}=$ Seedling treatment - lignite based culture of G. diazotrophicus $10 \mathrm{~kg}+$ PSB 1.25 $\mathrm{kg}$ in 100 lit water/ha (Drench the coco-pith trays containing 30 days old seedlings with this solution).

$\mathrm{T}_{6}=$ Seedling treatment - liquid culture of G. diazotrophicus@1 lit.+PSB @ 1 lit. in 100 lit water/ha ((Drench the coco-pith trays containing 30 days old seedlings with this solution).

$\mathrm{T}_{7}=$ Foliar spray of $G$. diazotrophicus liquid culture at 60 days after planting@1 lit. in 500 lit water/ha $+1.25 \mathrm{~kg}$ PSB soil application through $100 \mathrm{~kg}$ compost at 60 days after planting in furrows.

The data was analyzed statistically by using randomized block design as per procedure described by Panse and Sukhatme (1985).

\section{No. of millable canes (NMC)}

The NMC was significantly influenced by inoculation treatments. In general, the NMC 
ranged from 77,670 to 89,520 per hectare. Among the treatment $\mathrm{T}_{3}$ i.e. $50 \% \mathrm{~N}+$ Glucanoacetobacter lignite based set treatment recorded highest No. of millable canes $(89,520$ per hectare), however, it was at par with $\mathrm{T}_{2}$ i.e. $\mathrm{RDF}\left(100 \% \mathrm{~N}, \mathrm{P}_{2} \mathrm{O}_{5}\right.$ and $\left.\mathrm{K}_{2} \mathrm{O}\right)$ (86,220 per hectare), $\mathrm{T}_{4}$ i.e. $50 \% \mathrm{~N}+$ Glucanoacetobacter liquid based set treatment $\left(84,000\right.$ per hectare), $\mathrm{T}_{5}$ i.e. $50 \%$ $\mathrm{N}+$ Glucanoacetobacter lignite based seedling treatment $\left(86,220\right.$ per hectare), $\mathrm{T}_{6}$ i.e. $50 \% \mathrm{~N}+$ Glucanoacetobacter liquid based seedling treatment $\left(83,190\right.$ per hectare) and $\mathrm{T}_{7}$ i.e. $50 \% \mathrm{~N}+$ Glucanoacetobacter liquid based foliar spray treatment $(83,110$ per hectare).

\section{Cane yield (t/ha)}

The cane yield was significantly influenced by the inoculation treatments. The overall cane yield ranged from 87.87 to $121.66 \mathrm{t} / \mathrm{ha}$. Among the treatment $\mathrm{T}_{2}$ i.e. RDF $(100 \% \mathrm{~N}$, $\mathrm{P}_{2} \mathrm{O}_{5}$ and $\mathrm{K}_{2} \mathrm{O}$ ) recorded highest cane yield (121.66 tonn/ hectare), however, it was at par with $\mathrm{T}_{3}$ i.e. $50 \% \mathrm{~N}+$ Glucanoacetobacter lignite based set treatment, (120.83 tonn/ hectare), $\mathrm{T}_{4}$ i.e. $50 \% \mathrm{~N}+$ Glucanoacetobacter liquid based set treatment (117.19 tonn/ hectare), $\mathrm{T}_{5}$ i.e. $50 \% \mathrm{~N}+$ Glucanoacetobacter lignite based seedling treatment (117.85 tonn/ hectare), $\mathrm{T}_{6}$ i.e. $50 \% \mathrm{~N}+$ Glucanoacetobacter liquid based seedling treatment (115.58 tonn/ hectare) and $\mathrm{T}_{7}$ i.e. $50 \% \quad \mathrm{~N}+$ Glucanoacetobacter liquid based foliar spray treatment (113.80 tonn/ hectare).

\section{CCS yield (t/ha)}

The CCS yield was significantly influenced by the inoculation treatments. The overall CCS yield ranged from 11.38 to $17.60 \mathrm{t} / \mathrm{ha}$. Among the treatment $\mathrm{T}_{2}$ i.e. RDF $(100 \% \mathrm{~N}$, $\mathrm{P}_{2} \mathrm{O}_{5}$ and $\mathrm{K}_{2} \mathrm{O}$ ) recorded highest CCS yield (17.60 tonn/ hectare), however, it was at par with $\mathrm{T}_{3}$ i.e. $50 \% \mathrm{~N}+$ Glucanoacetobacter lignite based set treatment, (17.30 tonn/ hectare) and $\mathrm{T}_{5}$ i.e. $50 \% \quad \mathrm{~N}+$ Glucanoacetobacter lignite based seedling treatment (16.02 tonn/ hectare). These results are in conformity with those reported by Mehta et al., (1996), Kumar (2012) and Soomro et al., (2013) (Table 1).

Table.1

\begin{tabular}{|c|c|c|c|c|c|c|}
\hline $\begin{array}{l}\text { Tr. } \\
\text { No. }\end{array}$ & Treatment details & $\begin{array}{c}\text { NMC/ha } \\
\text { (1000) } \\
2016-17\end{array}$ & $\begin{array}{l}\text { Cane } \\
\text { yield } \\
\text { (t/ha) }\end{array}$ & $\begin{array}{l}\text { CCS } \\
\text { yield }\end{array}$ & Sucrose \% & $\begin{array}{l}\text { Microbial count } \\
\text { at harvest }\left(1^{4}\right)\end{array}$ \\
\hline $\mathbf{T}_{1}$ & Absolute Control & 77.67 & 87.87 & 11.38 & 18.91 & 4.67 \\
\hline $\mathbf{T}_{2}$ & RDF (100\% NPK) & 86.22 & 121.66 & 17.60 & 19.80 & 5.00 \\
\hline $\mathbf{T}_{3}$ & $\begin{array}{l}50 \% \mathrm{~N}+\text { Aceto lignite } \\
\text { based (set treat) }\end{array}$ & 89.52 & 120.83 & 17.30 & 20.30 & 8.83 \\
\hline $\mathbf{T}_{4}$ & $\begin{array}{l}50 \% \mathrm{~N}+\text { Aceto liquid } \\
\text { based (set treat) }\end{array}$ & 84.00 & 117.19 & 15.83 & 19.53 & 8.33 \\
\hline $\mathbf{T}_{5}$ & $\begin{array}{l}50 \% \mathrm{~N}+\text { Aceto lignite } \\
\text { based (seedling treat) }\end{array}$ & 86.22 & 117.85 & 16.02 & 20.12 & 8.67 \\
\hline $\mathbf{T}_{6}$ & $\begin{array}{l}50 \% \mathrm{~N}+\text { Aceto liquid } \\
\text { based (seedling treat) }\end{array}$ & 83.19 & 115.58 & 15.84 & 19.23 & 8.17 \\
\hline $\mathbf{T}_{7}$ & $\begin{array}{l}50 \% \text { N+ Aceto liquid } \\
\text { based (foliar Spray) }\end{array}$ & 83.11 & 113.80 & 15.25 & 19.13 & 7.17 \\
\hline & $\mathrm{SE} \pm$ & 2.09 & 2.56 & 0.54 & 0.29 & 0.27 \\
\hline & $\mathrm{CD}$ at $5 \%$ & 6.43 & 7.87 & 1.68 & 0.88 & 0.84 \\
\hline
\end{tabular}




\section{Sucrose $(\%)$}

The sucrose $\%$ was significantly influenced by the inoculation treatments. The overall sucrose \% ranged from 18.91 to $20.30 \%$. Among the treatment $\mathrm{T}_{3}$ i.e. $50 \% \mathrm{~N}+$ Glucanoacetobacter lignite based set treatment, recorded highest sucrose \% (20.30\%), however, it was at par with $\mathrm{T}_{2}$ i.e. RDF $\left(100 \% \mathrm{~N}, \mathrm{P}_{2} \mathrm{O}_{5}\right.$ and $\left.\mathrm{K}_{2} \mathrm{O}\right)(19.80 \%), \mathrm{T}_{4}$ i.e. $50 \% \mathrm{~N}+$ Glucanoacetobacter liquid based set treatment (19.53\%) and $\mathrm{T}_{5}$ i.e. $50 \% \mathrm{~N}+$ Glucanoacetobacter lignite based seedling treatment $(20.12 \%)$.

\section{Glucanoacetobacter count at harvest $\left(\mathbf{x 1 0 ^ { 4 } )}\right.$}

Among different treatments, the treatment $\mathrm{T}_{3}$ i.e. $50 \% \mathrm{~N}+$ Glucanoacetobacter lignite based set treatment, recorded significantly higher Glucanoacetobacter count $\left(8.83 \times 10^{4}\right)$ at harvest stage of the crop, This was at par with $\mathrm{T}_{4}$ i.e. $50 \% \mathrm{~N}+$ Glucanoacetobacter liquid based set treatment $\left(8.33 \times 10^{4}\right)$ and $\mathrm{T}_{5}$ i.e. $50 \%$ $\mathrm{N}+$ Glucanoacetobacter lignite based seedling treatment $\left(8.67 \times 10^{4}\right)$ at harvest stage of the crop.

In conclusion, the treatments, $\mathrm{T}_{3}$ i.e. $50 \% \mathrm{~N}+$ Glucanoacetobacter lignite based set treatment was found most effective than other treatment as it recorded the highest tillering count at 120 DAP, Total height, Cane girth, No. Internode, NMC, Brix, Sucrose Glucanoacetobacter population at harvest stage of the crop, however, it was at par with T2 i.e. $\mathrm{RDF}\left(100 \% \mathrm{~N}, \mathrm{P}_{2} \mathrm{O}_{5}\right.$ and $\left.\mathrm{K}_{2} \mathrm{O}\right)$, T4 i.e. $50 \% \mathrm{~N}+$ Glucanoacetobacter liquid based set treatment, T5 i.e. $50 \% \quad \mathrm{~N}+$ Glucanoacetobacter lignite based seedling treatment, T6 i.e. $50 \% \quad \mathrm{~N}+$ Glucanoacetobacter liquid based seedling treatment and $\mathrm{T} 7$ i.e. $50 \% \quad \mathrm{~N}+$ Glucanoacetobacter liquid based foliar spray treatment in most of growth, yield, microbial and quality parameter. Same result found in Rajkumar et al., study 2017. These result indicated that, set and seedling treatment (Drench the coco-pith trays containing 30 days old seedlings with this solution) of sugarcane with lignite based, liquid formulations and spray the liquid culture at 60 days after planting of G. diazotrophicus and PSB (soil application through $100 \mathrm{~kg}$ compost at 60 days after planting in furrows) will save

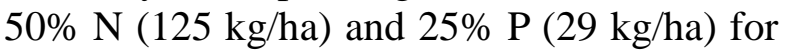
suru sugarcane besides the improved yield and quality and sustenance of soil fertility. Influence of application of phosphorus solubilizing bacteria (PSB), Bacillus megatherium var. Phosphaticum, at $10 \mathrm{~kg}$ ha -1 of lignite based culture with and without varying amounts of $P$ fertilizer was studied on soil available $P$ changes and sugarcane growth and yield. The PSB application increased the PSB population in the rhizosphere and the plant available $\mathrm{P}$ status in the soil. It also enhanced tillering, stalk population and stalk weight, and led to a cane yield increase of $12.6 \%$ over no application. When used in conjunction with $\mathrm{P}$ fertilizers, PSB reduced the required $\mathrm{P}$ dosage by $25 \%$, Sundra et al., (2002).

Similar results were also reported by Mehta $e t$ al., (1996), Chauhan et al., (2010) and Babar et al., (2011) who opined that apportioning of nitrogen dose through soil and that harvested from the air by the entophytic bacteria, substantiate the need of crop thereby improving the physiological conditions of photosynthetic activities leading to more yields. The rhizosphere soil condition with respect to moisture and other physical properties also plays a key role to accelerate the microbial activity, also might be due to drip irrigation which maintained the soil moisture.

\section{References}

Ando, S., 2010. Nitrogen fixation associated with endophytic bacteria. In Nitrogen Assimilation in Plants, Ed. Ohyama, 
T. and Sueyoshi, K. (Research Signpost, Kerala, India), pp. 215-231.

Babar, L., K., Iftikhar, T., Khan, H. N. and Makhdum, A. H. 2011. Agronomic trials on sugarcane crop under Faisalabad conditions, Pakistan. Pak. J. Bot., 43(2): 929-935.

Chauhan, H., Sharma, A. and Saini, S. K. 2010. Response of sugarcane to endophytic bacterial inoculation, Indian J. Sug. Tech. 25 (1\&2): 1-4.

Kaushal, A., Rahul Patole and Singh, K.G. 2012. Drip Irrigation in Sugarcane: A Review. Agri. Reviews, 33 (3): 211 219.

Kumar, N., 2012. Productivity, quality and nutrient balance in spring sugarcane (Saccharum spp. hybrid complex) under organic and inorganic nutrition, Indian J. Agron. 57(1): 68-73.

Mehta, H.N., Upadhyay, P. N., Chavda, J. R. and Patel, J. B. 1996. Effect of integrated nutrient management on yield, quality and economics of sugarcane (Saccharam officinaram). Indian J. Agron. 41(1). 176-178.

Panse, V.G., and Sukhatme, P. V. 1985. Statistical methods for agricultural workers. Fourth Ed. ICAR, New
Delhi. 157-165.

Rajkumar, B., B.D. Bhakare and Jana Harish. 2017. Effect of Consortium of Endophytic Nitrogen Fixing Bacteria on Yield Observations of Seasonal (Suru) Sugarcane under Drip Irrigation, International Journal of Current Microbiology and Applied Sciences ISSN: 2319-7706 Volume 6 Number 7 (2017) pp. 2789-2793

Reis, V., Lee, S. and Kennedy, C. 2007. Biological nitrogen fixation in sugarcane. p. 213-232. In: Associative and Endophytic Nitrogen-fixing Bacteria and Cyanobacterial Associations, Ed. Emerich, C. and Newton W.E., Springer, Dordrecht, The Netherlands. pp. 213-232.

Soomro, A.F., Tunio, S., Oad, F.C. and Rajper, I. 2013. Integrated effect of inorganic and organic fertilizers on the yield and quality of sugarcane (Saccharum officinarum L). Pak. J. Bot., 45(4): 1339-1348.

Sundra B., Natrajan V.N., and H. hari,. 2002. Influence of $\mathrm{P}$ soluble sing bacteria on the change of soil available $\mathrm{P}$ and sugarcane field. Field crop sciences. 77(1): 43-49.

\section{How to cite this article:}

Khandagale, P.P., M.M. Keskar, S.K. Ghodke and Raskar, B.S. 2019. Study the Effect of Glucanoacetobacter diazotrophicus and PSB Formulations on Quality Parameter on suru Sugarcane. Int.J.Curr.Microbiol.App.Sci. 8(05): 938-942.

doi: https://doi.org/10.20546/ijcmas.2019.805.108 